Diabetologia $10,71-76(1975)$

(C) by Springer-Verlag 1975

\title{
An Apparent Abnormality of the B-Cell Microtubular System in Spiny Mice (Acomys Cahirinus)*
}

\author{
F. Malaisse-Lagae, M. Ravazzola, M. Amherdt, A. Gutzeit, W. Stauffacher**, W. J. Malaisse*** and L. Orci \\ Institut d'Histologie et d'Embryologie, and Institut de Biochimie Clinique, University of Geneva, Switzerland \\ Received: August 4, 1974, and in revised form: October 23, 1974
}

Summary. The pancreatic B-cell contains microtubules, which are thought to participate in the process of insulin release. In order to disclose a possible abnormality of this B-cell microtubular system in animals with islet dysfunction, isolated islets from normal rats and mice, as well as from diabetic mutant mice (DBM mice) and from spiny mice (Acomys cahirinus) were incubated in the presence of vincristine, which causes the precipitation of the microtubular protein into paracrystalline deposits. Ultrastructural examination of the islets indicated that the volume-density of vincristine-induced deposits was markedly reduced in B-cells of spiny mice, when compared to that found in normal rats and mice and DBM mice. Exposure of the islets from spiny mice to a high glucose concentration, concomittantly to vincristine, caused a further reduction in vincristine-induced crystals content of the B-cell. It is speculated that an impairment of the B-cell microtubular system may account for the deficiency of insulin release found in spiny mice.

Key-words: B-cell microtubules, spontaneous diabetes, spiny mice (Acomys cahirinus), DBM mice, isolated islets, vincristine-induced crystals, electron microscopy, morphometry.
Microtubules are thought to be involved in maintenance of cell shape [1,2], in cell motion [3], cell division $[4,5]$ and in controlled movements of intracellular organelles $[6,7,8]$. In the pancreatic B-cell, they are apparently participating in the process of insulin release $[9,10,11]$. It is, therefore, theoretically conceivable that a primary anomaly of the microtubular system contributes to abnomalities of insulin release. In order to test such an hypothesis, an attempt was made to compare the microtubular content of B-cells from normal rats and mice, and of two strains of rodents with abnormal islet function.

A quantitative assessment of the number of microtubules present in a given cell is hampered, inter alia, by the fact that the identification of these organelles, which are scattered throughout the cytoplasm, may be ambiguous, depending on their plane of section. In order to overcome this difficulty, isolated islets of Langerhans were exposed to vincristine, which is known to cause the precipitation of the microtubular protein into massive paracrystalline deposits easily identifiable by electron microscopy [12]. The volume-density of vincristine-induced crystals in B-cells cytoplasm was

* Supported by the Fonds National Suisse de la Recherche Scientifique (grants $3.553 .71,3.8080 .72,3.0310 .73$ and 3.1060 . 73 SR).

** Present address: Department of Medicine, University of Bern, Switzerland.

*** Invited Professor at the University of Geneva and recipient of a Pfizer Travel Award through the European Association for the Study of Diabetes. determined by morphometry [13] and was assumed to reflect the content of microtubular protein in Bcells $[14,15]$.

Preliminary results were reported in an abstract form [16]. The present study was presented at the Third Brook Lodge Workshop on spontaneous Diabetes in Laboratory animals (Augusta, Michigan, May $2-4,1974)$.

\section{Material and Methods}

Animals

Six groups of animals were used in this study:

Group 1. Five 4 months-old female rats, from a Wistar-derived colony maintained at the Institut de Biochimie Clinique;

Group 2. Five 5 months-old male Swiss Albino mice (purchased from S. Ivanovas, Kisslegg, Germany);

Group 3. Five $4^{1 / 2}$ months-old male black mice (C57 Bl/6 +/ +, purchased from the Jackson Memorial Laboratories, Bar Harbor, Maine, U.S.A.), serving as controls for the DBM mice;

Groups 4 and 5: 4 male and 6 female Diabetic Mutant mice (DBM mice), 41/2 months-old, bred from a stock kindly donated by Dr A. A. Like (Elliott P. Joslin Laboratory, Boston, Massachusetts, U.S.A.). Five days before the experiment, these mice were bled from the orbital sinus for determination of their fasting plasma glucose concentration, according to which they were divided in "normoglycemic" (group 4) and "hyperglycemic" (group 5); 
Group 6. Five male and two female spiny mice (Acomys cahirinus) 31/2 to 4 months-old, derived from a stock colony maintained at the Institut de Biochimie Clinique. Two weeks before sacrifice, they were submitted to an intravenous glucose tolerance test [17]. As expected from previous studies [18-20], their insulin secretory reponse to glucose displayed a both delayed and abnormally low pattern. shown in Table 1 refer to fasting values 5 days before sacrifice. The pancreas of each animal was rapidly dissected, minced, and individually digested at $37^{\circ} \mathrm{C}$ with a fixed amount of collagenase $(10 \mathrm{mg}$; Worthington, Freehold, New Jersey, U.S.A.) in $1 \mathrm{ml}$ of Hanks buffer (21). The isolated islets were placed in $1.0 \mathrm{ml}$ of bicarbonate-buffered medium ( $\mathrm{pH} 7.4)$, containing glucose $(1.0 \mathrm{mg} / \mathrm{ml})$, albumin $(5.0 \mathrm{mg} / \mathrm{ml})$ and vincris-

Table 1. Individual data, at the time of sacrifice, for body weight, plasma glucose and immunoreactive insulin (IRI) and volume-density of vincristine-induced crystals in B-cells cytoplasm

\begin{tabular}{|c|c|c|c|c|c|}
\hline & $\begin{array}{l}\text { Animal } \\
\mathrm{Nr}\end{array}$ & $\begin{array}{l}\text { Body Wt } \\
\text { g }\end{array}$ & $\begin{array}{l}\text { Plasma glucose } \\
\mathrm{mg} / 100 \mathrm{ml}\end{array}$ & $\begin{array}{l}\text { Plasma IRI } \\
\mathrm{ng} / \mathrm{ml}\end{array}$ & $\begin{array}{l}\text { Volume Density } \\
\text { of Crystals } \\
\text { per cent }\end{array}$ \\
\hline Rats & $\begin{array}{l}1 \\
2 \\
3 \\
4 \\
5\end{array}$ & $\begin{array}{l}273 \\
203 \\
242 \\
240 \\
218\end{array}$ & $\begin{array}{l}126 \\
155 \\
141 \\
137 \\
175\end{array}$ & $\begin{array}{l}1.68 \\
1.25 \\
0.96 \\
1.36 \\
3.40\end{array}$ & $\begin{array}{l}1.48 \pm 0.23 \\
1.20 \pm 0.13 \\
2.06 \pm 0.48 \\
1.90 \pm 0.27 \\
1.11 \pm 0.24\end{array}$ \\
\hline $\begin{array}{l}\text { Swiss } \\
\text { Mice }\end{array}$ & $\begin{array}{l}1 \\
2 \\
3 \\
4 \\
5\end{array}$ & $\begin{array}{l}48.7 \\
42.0 \\
39.8 \\
44.6 \\
47.0\end{array}$ & $\begin{array}{l}214 \\
179 \\
189 \\
160 \\
155\end{array}$ & $\begin{array}{l}5.70 \\
4.15 \\
2.35 \\
3.85 \\
2.30\end{array}$ & $\begin{array}{l}0.84 \pm 0.24 \\
1.07 \pm 0.29 \\
1.41 \pm 0.24 \\
0.94 \pm 0.13 \\
1.40 \pm 0.14\end{array}$ \\
\hline $\begin{array}{l}\text { C57/b1 } \\
\text { Mice }\end{array}$ & $\begin{array}{l}1 \\
2 \\
3 \\
4 \\
5\end{array}$ & $\begin{array}{l}29.3 \\
31.3 \\
26.0 \\
24.4 \\
27.0\end{array}$ & $\begin{array}{l}113 \\
165 \\
156 \\
156 \\
153\end{array}$ & $\begin{array}{l}1.16 \\
0.50 \\
0.78 \\
0.82 \\
1.16\end{array}$ & $\begin{array}{l}0.96 \pm 0.33 \\
1.15 \pm 0.28 \\
0.27 \pm 0.10 \\
1.44 \pm 0.24 \\
1.03 \pm 0.34\end{array}$ \\
\hline $\begin{array}{l}\text { DBM Mice } \\
\text { Normogl. }\end{array}$ & $\begin{array}{l}1 \\
2 \\
3 \\
4 \\
5\end{array}$ & $\begin{array}{l}60.7 \\
52.8 \\
50.0 \\
52.4 \\
44.1\end{array}$ & $\begin{array}{r}68^{*} \\
118^{*} \\
86^{*} \\
75^{*} \\
118^{*}\end{array}$ & $\begin{array}{l}32.0^{*} \\
32.0^{*} \\
34.4^{*} \\
38.6^{*} \\
32.8^{*}\end{array}$ & $\begin{array}{l}0.85 \pm 0.19 \\
1.69 \pm 0.45 \\
1.25 \pm 0.28 \\
0.53 \pm 0.13 \\
1.28 \pm 0.26\end{array}$ \\
\hline $\begin{array}{l}\text { DBM Mice } \\
\text { Hypergl. }\end{array}$ & $\begin{array}{l}1 \\
2 \\
3 \\
4 \\
5\end{array}$ & $\begin{array}{l}45.9 \\
48.3 \\
43.3 \\
36.3 \\
50.4\end{array}$ & $\begin{array}{l}179^{*} \\
216^{*} \\
251^{*} \\
383^{*} \\
225^{*}\end{array}$ & $\begin{array}{r}29.6^{*} \\
27.2^{*} \\
45.8^{*} \\
5.0^{*} \\
48.2^{*}\end{array}$ & $\begin{array}{l}1.36 \pm 0.41 \\
1.07 \pm 0.31 \\
1.15 \pm 0.22 \\
1.10 \pm 0.39 \\
1.06 \pm 0.21\end{array}$ \\
\hline Acomys & $\begin{array}{l}1 \\
2 \\
3 \\
4 \\
5 \\
6 \\
7\end{array}$ & $\begin{array}{l}42.0 \\
44.6 \\
37.4 \\
39.6 \\
42.0 \\
39.0 \\
37.0\end{array}$ & $\begin{array}{l}136 \\
126 \\
131 \\
131 \\
170 \\
222 \\
113\end{array}$ & $\begin{array}{l}0.65 \\
1.05 \\
1.17 \\
0.94 \\
1.58 \\
2.85 \\
0.60\end{array}$ & $\begin{array}{l}0.36 \pm 0.10 \\
0.17 \pm 0.07 \\
0.38 \pm 0.22 \\
0.30 \pm 0.15 \\
0.45 \pm 0.11 \\
0.40 \pm 0.09 \\
0.28 \pm 0.13\end{array}$ \\
\hline
\end{tabular}

The asterisks indicate fasting values obtained 5 days before sacrifice. The mean value ( \pm SEM) for the volume density of crystals refers, in each case, to five measurements performed in different islets (see Material and Methods).

\section{Experimental Procedure}

The animals were fed ad libitum on laboratory chow until killed by decapitation, at which time blood was obtained for the determination of plasma glucose and immunoreactive insulin (IRI) concentrations (Table 1). In the case of DBM mice, however, the data tine $(10 \mathrm{mcg} / \mathrm{ml}$; Oncovin, Lilly, Indianapolis, Indiana, U.S.A.), and equilibrated with $\mathrm{O}_{2} 95 \%-\mathrm{CO}_{2} 5 \%$. Incubation was carried out for 3 hours at $37^{\circ} \mathrm{C}$. A few islets from the rats and from the Acomys were also incubated in the presence of vincristine at a higher glucose concentration $(5.0 \mathrm{mg} / \mathrm{ml})$. At the end of incubation, the islets were fixed with glutaraldehyde $2 \%$ 
in phosphate buffer (0.1 M; pH 7.4), post-fixed with $2 \%$ phosphate-buffered $\mathrm{OsO}_{4}(22)$, dehydrated with alcohol and embedded in Epon 812. Thin sections of islets, stained with uranyl-acetate followed by lead citrate, were examined in a Philips 300 electron microscope.

\section{Quantitative Estimation of Vincristine-Induced Deposits}

Five islets from each animal were examined and, for each islet, four micrographs of B-cells were taken at random. The volume-density of vincristine-induced deposits in B-cells cytoplasm was determined for each islet by point-counting [13] of the micrographs printed at a final magnification of 17,000 .
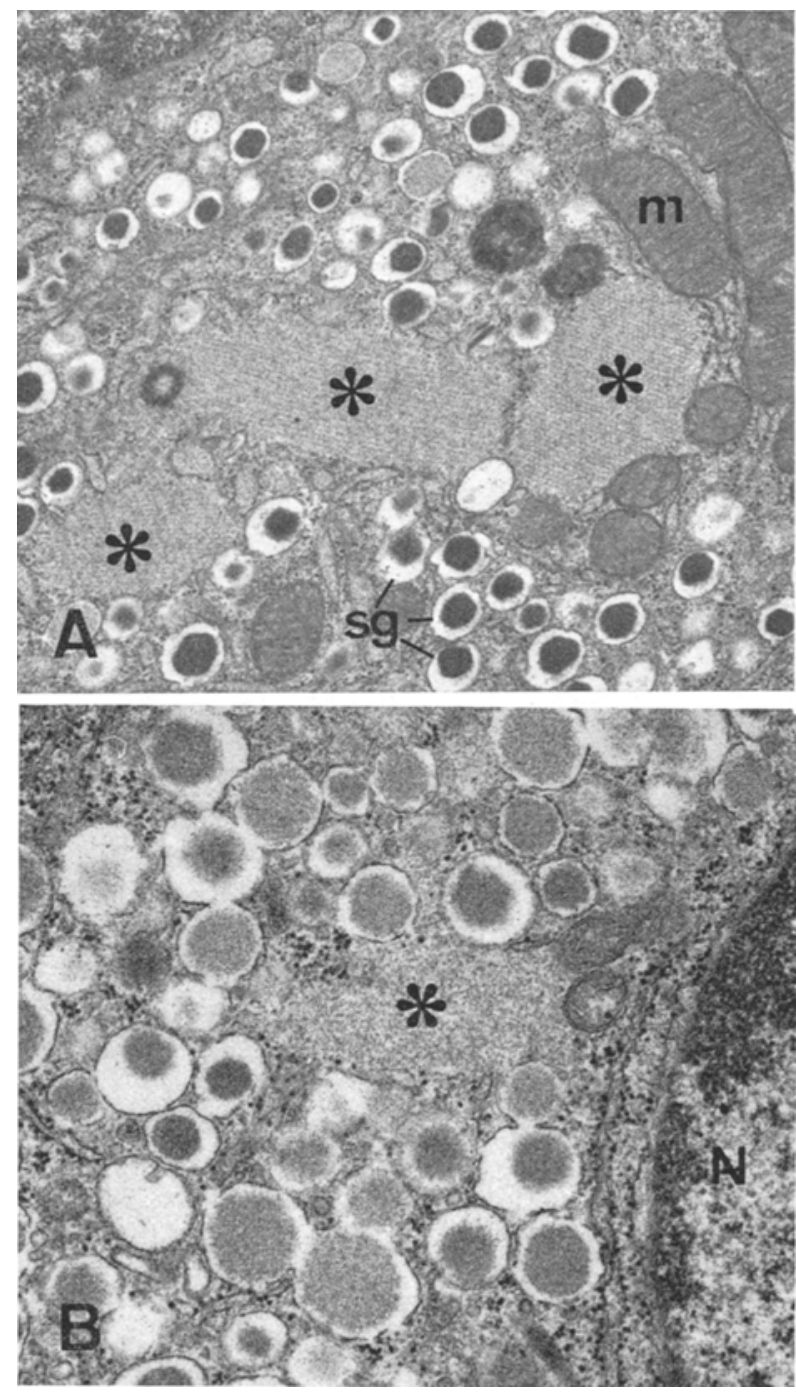

Fig. 1. Isolated islets incubated with vincristine. $A$ ) B-cell of a Swiss mouse: three vincristine-induced paracrystalline deposits (asterisks) are seen. $\mathrm{sg}=$ secretory granules; $\mathrm{m}=$ mitochondrion (X 15,000). B) B-cell of a spiny mouse. The asterisk indicates a poorly developed paracrystalline deposit. $\mathbf{N}=$ nucleus (X 23,000)

\section{Results}

Vincristine-induced crystals were found in B-cells, as well as in A-cells and other endocrine and nonendocrine cells (fibroblasts, endothelial cells) within the islets of all groups studied. In B-cells, crystals were frequently observed in the paranuclear region, but also scattered throughout the cytoplasm where they were often surrounded by secretory granules, mitochondria and electron-lucent vacuoles (Fig. 1).

As illustrated in Figs. 2 and 3, the volume density of vincristine-induced crystals in B-cells cytoplasm was much lower in the spiny mice (Acomys cahirinus) than in any other group. This reduction in volume density was highly significant. In contrast, no significant difference could be detected between the four groups of mice (Mus musculus), including the hyperglycemic DBM mice. There was a tendency for higher values in rats than in mice, but the latter difference failed to achieve statistical significance when the comparison was based on the mean values obtained in each animal (see Fig. 3, "individual data").

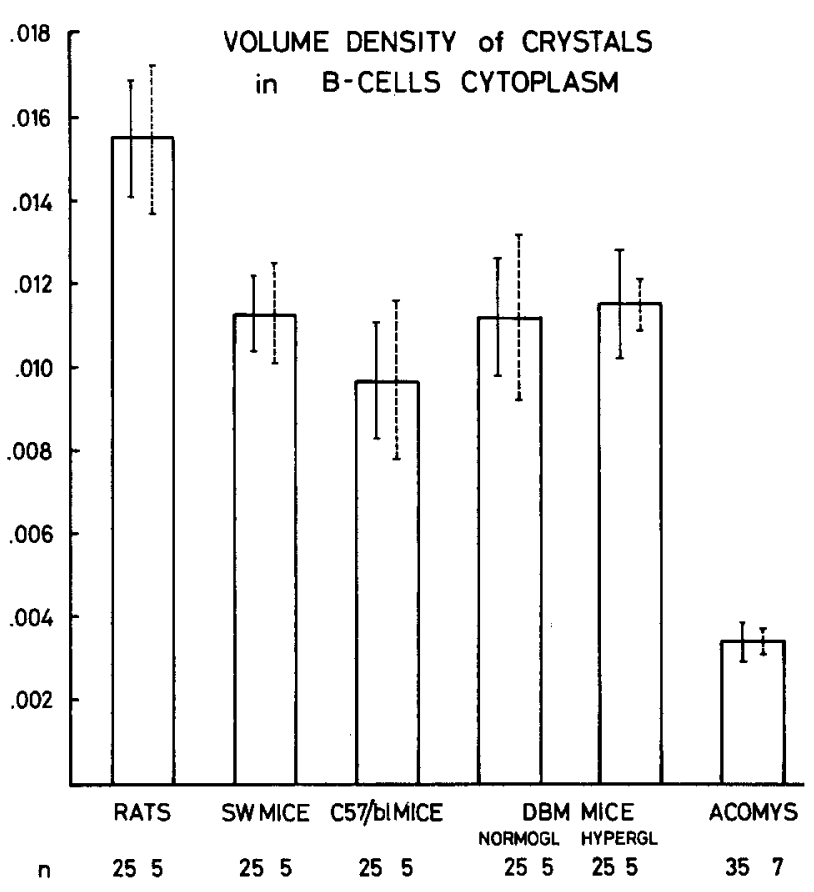

Fig. 2. Mean values for the volume density of vincristineinduced crystals in B-cells cytoplasm are shown, with their SEM, which were calculated either from the measurements performed in each islet (solid bars) or only from the average value obtained in each animal (broken bars)

Because glucose could conceivably affect the turnover or the reactivity to vincristine of the microtubular protein, an additional set of experiments was performed at high glucose concentration. As indicated 


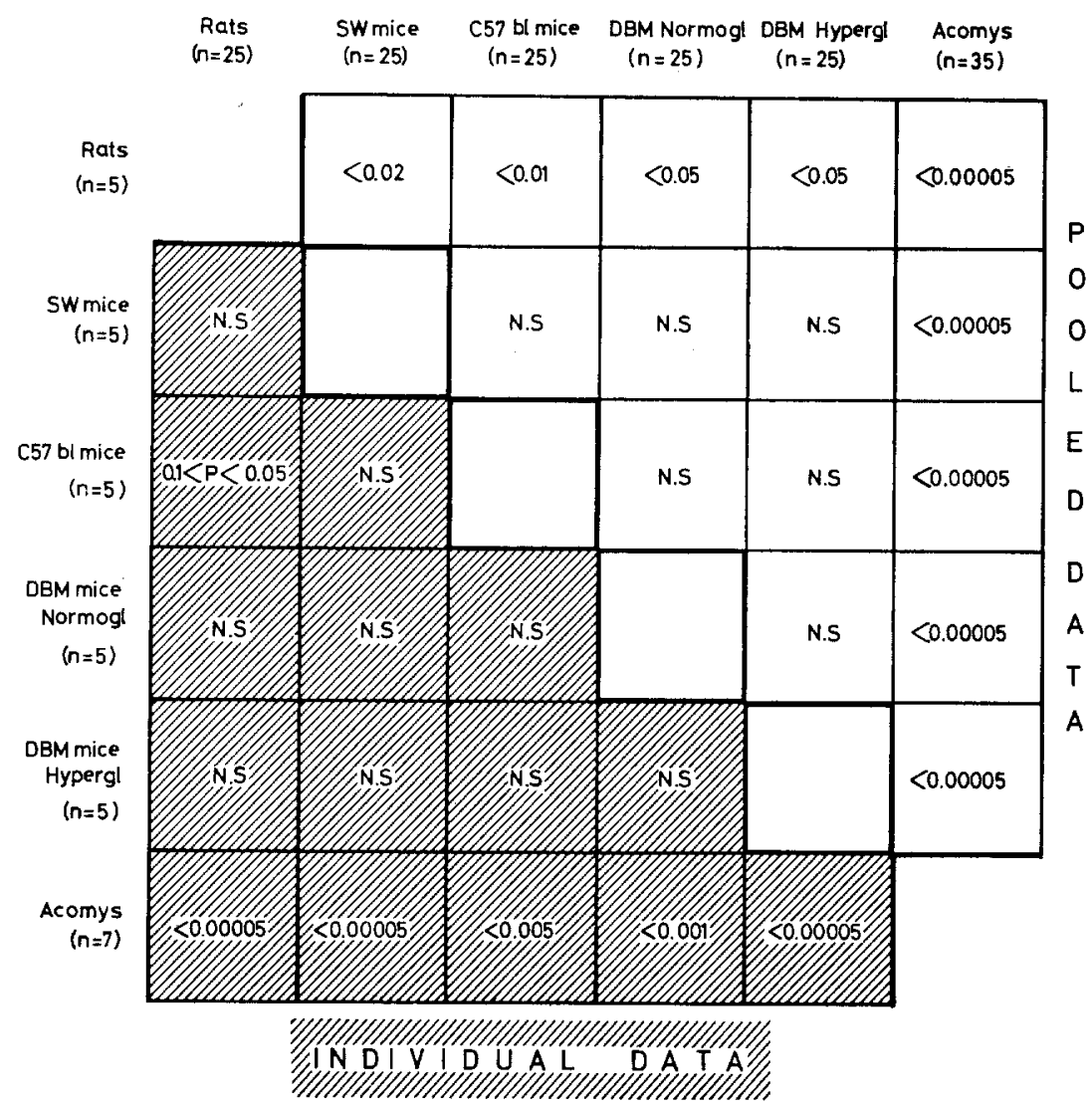

Fig. 3. The statistical significance for the differences between mean densities of vincristine induced deposits in each group was calculated either for the measurements performed in each islet ("pooled data" and open blocks), or for the average value obtained in each animal ("individual data" and cross-hatched blocks)

in Table 2, the use of such a high glucose concentration failed to affect significantly the volume density of vincristine-induced deposits in B-cells from rats, whereas it provoked a further reduction of this variable in the Acomys.

\section{Discussion}

We have assumed that the density of vincristineinduced crystals reflects the relative abundance of microtubular protein, and hence the number of microtubules in B-cells. This assumption is supported by a number of studies which suggest that the formation of vincristine-induced crystals is indeed an indicator of the presence of microtubules in various cell types [10, $14,15,23-25]$. Moreover, in pancreatic tissue or isolated islets exposed to vincristine, the disappearance of microtubules and the appearance of crystals follow a synchronous pattern [26]. It could be argued that the reduced density of crystals in B-cells of spiny mice reflects an abnormal interaction between vincristine and the microtubular protein. In our view, such an hypothesis is unlikely, since an apparent reduction in the number of microtubules in B-cells of spiny mice was indeed observed (unpublished observations), and prompted us to complete the present study.

Recent studies on the influence of vincristine and colchicine upon glucose-induced insulin release by the isolated perfused rat pancreas [26-29] have led to the view that the B-cell microtubular apparatus is mainly responsible for the provision of secretory granules from a large storage compartment to a peripheral and readily releasable pool. Within the framework of such a concept, the impairment of the B-cell microtubular system in spiny mice, as revealed by the present study, would lead to a permanent depletion of the labile pool of beta granules. In turn, such an abnormality could account for the paradoxical situa- 
Table 2. Influence of glucose upon the volume density of vincristine-induced crystals in B-cells

Volume density of vincristine-induced crystals $\times 10^{-2}$

\begin{tabular}{|c|c|c|c|c|c|c|}
\hline & \multicolumn{3}{|c|}{ RATS } & \multicolumn{3}{|c|}{ ACOMYS } \\
\hline & Gluc. 100 & Gluc. 500 & $\mathrm{p}$ & Gluc. 100 & Gluc. 500 & P \\
\hline 1 & $1.48 \pm 0.23$ & $1.51 \pm 0.19$ & NS & $0.36 \pm 0.10$ & $0.11 \pm 0.11$ & $<0.2$ \\
\hline 2 & $1.20 \pm 0.13$ & $1.76 \pm 0.35$ & $<0.2$ & $0.17 \pm 0.07$ & $0.04 \pm 0.03$ & $<0.2$ \\
\hline 3 & $2.06 \pm 0.48$ & $1.38 \pm 0.32$ & NS & $0.38 \pm 0.22$ & $0.00 \pm 0.00$ & $<0.2$ \\
\hline 4 & $1.90 \pm 0.27$ & $1.86 \pm 0.43$ & NS & $0.30 \pm 0.15$ & $0.28 \pm 0.17$ & NS \\
\hline 5 & $1.11 \pm 0.24$ & $1.80 \pm 0.55$ & NS & $0.45 \pm 0.11$ & $0.20 \pm 0.08$ & $<0.2$ \\
\hline Mean values & & & & & & \\
\hline $\mathrm{n}=25$ & $1.55 \pm 0.14$ & $1.66 \pm 0.16$ & NS & $0.33 \pm 0.06$ & $0.13 \pm 0.05$ & $<0.01$ \\
\hline $\mathrm{n}=5$ & $1.55 \pm 0.19$ & $1.66 \pm 0.12$ & NS & $0.33 \pm 0.05$ & $0.13 \pm 0.05$ & $<0.02$ \\
\hline$\frac{\text { Paired }}{\text { differences }}$ & +0.11 & 0.24 & NS & -0.21 & 0.06 & $<0.05$ \\
\hline
\end{tabular}

Isolated islets removed from either rats or Acomys were incubated for 180 minutes in the presence of vincristine (10 microg/ml) at either a low $(100 \mathrm{mg} / \mathrm{ml})$ or high $(500 \mathrm{mg} / 100 \mathrm{ml})$ glucose concentration. The statistical significance of differences (P) was calculated (i) for the five measurements performed in each animal at each glucose concentration (upper part); (ii) for the 25 measurements performed in each group; and (iii) for the mean values obtained in each animal ( $\mathrm{n}=5$ ) the latter difference being tested by both group and paired comparison.

tion found in spiny mice: i.e. an abnormally low immediate insulin secretory response to various secretagogues coexisting with apparently intact synthesis and storage of the hormone in the B-cell $[18-20,30$, 31].

In contrast, in DBM mice, the diabetic syndrome does not appear to be due to a primary defect of the insulin releasing process $[19,20]$. The observation of a normal microtubular protein content in the B-cells of DBM mice, which is compatible with such a view, further suggests that the abnormality found in spiny mice might represent an uncommon cause of islet dysfunction.

\section{References}

1. Tilney, L. G., Hiramoto, Y., Marsland, D.: Studies on the microtubules in Helizoa. III. A pressure analysis of the role of these structures in the formation and maintenance of the axopodia of Actinosphaerium nucleofilum (Barrett). J. Cell Biol. 29, 77-95 (1966)

2. Behnke, O.: A comparative study of microtubules of diskshaped blood cells. J. Ultrastruct. Res. 31, 61-75 (1970)

3. Freed, J. J., Bhisey, A. N., Lebowitz, M. M.: The relation of microtubules and microfilaments to the motility of cultured cells. J. Cell Biol. 39, 46a (1968)
4. de Harven, E.: The centriole and the mitotic spindle. In: Ultrastructure in biological systems, p. 197-227, vol. 3. (ed. by Dalton, A. J., Haguenau, F.) New York, London: Academic Press 1968

5. Wilson, H. J.: Arms and bridges on microtubules in the mitotic apparatus. J. Cell Biol. 40, 854-859 (1969)

6. Dahlström, A., Häggendal, J .:Studies on the transport and life-span of amino acid storage granules in a peripheral adrenergic neuron system. Acta physiol. scand. 67, 278288 (1966)

7. Freed, J. J., Lebowitz, M. M.: The association of a class of saltatory movements with microtubules in cultured cells. J. Cell. Biol. 45, 334-354 (1970)

8. Rebhun, L. I.: Polarized intracellular particle transport: saltatory movements and cytoplasmic streaming. Int. Rev. Cytol. 32, 93-137 (1972)

9. Lacy, P. E., Howell, S. L., Young, D. A., Fink, C. J.: New hypothesis of insulin secretion. Nature 219, 1177$1179(1968)$

10. Malaisse-Lagae, F., Greider, M. H., Malaisse, W. J., Lacy, P. E.: The stimulus secretion coupling of glucose-induced insulin release. IV. The effect of vincristine and deuterium oxide on the microtubular system of the beta cell. J. Cell. Biol. 49, 530-535 (1971)

11. Malaisse, W. J., Malaisse-Lagae, F., Walker, M. O., Lacy, P. E.: The stimulus-secretion coupling of glucose induced insulin release. V. The participation of a microtubularmicrofilamentous system. Diabetes 20, 257-265 (1971)

12. Bensch, K. G.. Malawista. S. E.: Microtubule crystals: 
A new biophysical phenomenon, induced by Vinca alkaloids. Nature 218, 1176 (1968)

13. Weibel, E. R.: Stereological principles for morphometry in electron microscopic cytology. Int. Rev. Cytol. 26, 235-302 (1969)

14. Bensch, K. G., Malawista, S. E.: Microtubular crystals in mammalian cells. J. Cell Biol. 40, 95-107 (1969)

15. Krishan, A., Hsu, D.: Binding of colchicine- ${ }^{8} \mathrm{H}$ to vinblastine-induced crystals in mammalian tissue culture cells. J. Cell. Biol. 48, 407-409 (1971)

16. Malaisse-Lagae, F., Amherdt, M., Ravazzola, M., Stauffacher, W., Orci, L., Renold, A. E.: A peculiarity of the B-cell microtubules in spiny mice. Diabetologia 9, 80, (1973)

17. Gutzeit, A., Rabinovitch, A., Studer, P. P., Trueheart, P. A., Cerasi, E., Renold, A. E.: Decreased intravenous glucose tolerance and low plasma insulin response in spiny mice (Acomys cahirinus). Diabetologia 10, 667670 (1974)

18. Cameron, D. P., Stauffacher, W., Orci, L., Amherdt, M., Renold, A. E.: Defective immunoreactive insulin secre tion in the Acomys cahirinus. Diabetes 32, 1060-1071 (1972)

19. Cameron, D. P., Amherdt, M., Orci, L., De Peyer, R., Stauffacher, W.: Biochemical and morphological studies of immunoreactive insulin secretion in spontaneous and acquired obesity and/or hyperglycemia in rodents. Acta diabet. lat. 9 (Suppl. 1), 89-140 (1972)

20. Cameron, D. P., Stauffacher, W., Amherdt, M., Orci, L., Renold, A. E.: Kinetics of immunoreactive insulin release in obese hyperglycemic laboratory rodents. Endocrinology 92, 257-264 (1973)

21. Lacy, P. E., Kostianovsky, M.: Method for the isolation of intact islets of Langerhans from the rat pancreas. Diabetes 16, 35-39 (1967)

22. Millonig, G.: Further observations on a phosphate buffer for osmium solutions in fixations. Fifth International Congress for Electron Microscopy, Philadelphia, p. 8, (ed. S. S. Breese, Jr.,) New York: Academic Press (1962)

23. Marantz, R., Ventilla, M., Shelansky, M. L.: Vinblastineinduced precipitation of microtubule protein. Science $\mathbf{1 6 5}$, 498-499 (1969)

24. Shelansky, M. L., Ventilla, M.: The chemistry of experimentally induced aggregate of microtubule protein.
Sixth Congress of Neuropathology, p. 84-85. Paris: Masson et Cie (1970)

25. Nève, P., Willems, C., Dumont, J. E.: Involvement of the microtubule-microfilament system in thyroid secretion. Exp. Cell Res. 63, 457-460 (1970)

26. Devis, G., Van Obberghen, E., Somers, G., Malaisse-Lagae, F., Orci, L., Malaisse, W. J.: Dynamics of insulin release and microtubular-microfilamentous system. II. Effect of vincristine. Diabetologia 10, 53-59 (1974)

27. Somers, G., Van Obberghen, E., Devis, G., Ravazzola, M., Malaisse-Lagae, F., Malaisse, W. J.: Dynamics of insulin release and microtubular-microfilamentous system. III. Effect of colchicine upon glucose-induced insulin secretion. Europ. J. clin. Invest. 4, 299-305 (1974)

28. Van Obberghen, E., Devis, G., Somers, G., Ravazzola, M., Malaisse-Lagae, F., Malaisse, W. J.: Dynamics of insulin release and microtubular-microfilamentous system. IV. Effect of colchicine upon sulfonylurea-induced insulin secretion. Europ. J. clin. Invest. 4, 307-312 (1974)

29. Malaisse, W. J., Van Obberghen, E., Devis, G., Somers, G., Ravazzola, M.: Dynamics of insulin release and microtubular-microfilamentous system. V. A model for the phasic release of insulin. Europ. J. clin. Invest. 4, 313-318 (1974)

30. Stauffacher, W., Orci, L., Amherdt, M., Burr, I. M., Balant, L., Froesch, E. R., Renold, A. E.: Metabolic state, pancreatic insulin content and B-cell morphology of normoglycemic spiny mice (Acomys cahirinus): Indications for an impairment of insulin secretion. Diabetologia 6, 330342 (1970)

31. Amherdt, M., Orci, L., Stauffacher, W., Renold, A. E., Rouiller, Ch.: Morphological evidence suggestive of an impairment of insulin secretion in vivo in normoglycemic spiny mice (Acomys cahirinus). Proc. 7th International Congress of Electron Microscopy. p. 501. Paris: Soc. Française de Microscopie Electronique (1970)

\author{
Dr. F. Malaisse-Lagae \\ Institut d'Histologie \\ et d'Embryologie \\ Ecole de Médecine \\ CH-1211 Genève 4 \\ Switzerland
}

